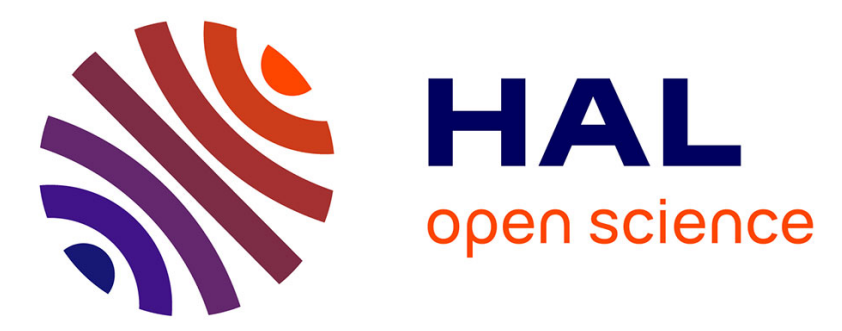

\title{
Safety and efficacy of pegylated interferon and ribavirin in adolescents with human immunodeficiency virus and hepatitis $\mathrm{C}$ virus acquired perinatally
}

Raffaella Rosso, Antonio Di Biagio, Malgorzata Mikulska, Elena Nicco, Claudia Bernardini, Claudio Viscoli

\section{To cite this version:}

Raffaella Rosso, Antonio Di Biagio, Malgorzata Mikulska, Elena Nicco, Claudia Bernardini, et al.. Safety and efficacy of pegylated interferon and ribavirin in adolescents with human immunodeficiency virus and hepatitis C virus acquired perinatally. Journal of Medical Virology, 2010, 82 (7), pp.1110. 10.1002/jmv.21802 . hal-00552414

\section{HAL Id: hal-00552414 https://hal.science/hal-00552414}

Submitted on 6 Jan 2011

HAL is a multi-disciplinary open access archive for the deposit and dissemination of scientific research documents, whether they are published or not. The documents may come from teaching and research institutions in France or abroad, or from public or private research centers.
L'archive ouverte pluridisciplinaire HAL, est destinée au dépôt et à la diffusion de documents scientifiques de niveau recherche, publiés ou non, émanant des établissements d'enseignement et de recherche français ou étrangers, des laboratoires publics ou privés. 


\section{Safety and efficacy of pegylated interferon and ribavirin in adolescents with human immunodeficiency virus and hepatitis $\mathrm{C}$ virus acquired perinatally}

\begin{tabular}{|r|l|}
\hline Journal: & Journal of Medical Virology \\
\hline Manuscript ID: & JMV-09-1595.R3 \\
\hline Datey - Manuscript type: & Research Article \\
\hline Author: & 11 -Feb-2010 \\
\hline & $\begin{array}{l}\text { Rosso, Raffaella; University of Genoa, Infectious Diseases } \\
\text { Di Biagio, Antonio; San Martino Hospital, Infectious Diseases } \\
\text { Nicco, Elena; University of Genoa, Infectious Diseases } \\
\text { Bernardini, Claudia; University of Genoa, Infectious Diseases } \\
\text { Viscoli, Claudio; University of Genoa, Infectious Diseases }\end{array}$ \\
\hline Keywords: & $\begin{array}{l}\text { hepatitis C virus, ribavirin, pegylated interferon, mother-to-child } \\
\text { transmission, human immunodeficiency virus }\end{array}$ \\
\hline
\end{tabular}

\section{今scholarONE \\ Manuscript Central}


Table 1. Characteristics of individuals included in case series

\begin{tabular}{|c|c|c|c|c|c|c|c|c|c|c|c|c|c|c|c|c|c|}
\hline Patient & Age & Gender & $\begin{array}{c}\text { Weight } \\
\text { (Kg) }\end{array}$ & CDC & CD4+ & $\begin{array}{l}\text { HIV-RNA } \\
\text { copies/mL }\end{array}$ & Genotype & $\begin{array}{r}\text { HCV } \\
\text { VL } \\
\log _{10}\end{array}$ & ALT/AST & $\begin{array}{l}\text { PEG } \\
\text { IFN } \\
\text { mcg }\end{array}$ & $\begin{array}{c}\text { Ribavirin } \\
\text { mg }\end{array}$ & ARV & $\begin{array}{c}\text { Change } \\
\text { ARV } \\
\text { During } \\
\text { HCV } \\
\text { therapy }\end{array}$ & $\begin{array}{c}\text { Weeks } \\
\text { of PEG- } \\
\text { IFN/ } \\
\text { ribavirin }\end{array}$ & RVR & EVR & SVR \\
\hline 2 & 18 & F & 66 & B2 & 474 & $<50$ & $3 a$ & $\begin{array}{c}1.42 \mathrm{x} \\
10^{6}\end{array}$ & $220 / 122$ & $\begin{array}{c}\text { alfa } 2 b \\
100\end{array}$ & 800 & $\begin{array}{c}\mathrm{ABC}+ \\
3 \mathrm{TC}+ \\
\mathrm{LPV} / \mathrm{rtv}\end{array}$ & no & 36 & yes & yes & yes \\
\hline $4 \mathrm{R}$ & 20 & $\mathrm{~F}$ & 49 & A2 & 681 & $<50$ & $3 a$ & $\begin{array}{c}5.19 \mathrm{x} \\
10^{4}\end{array}$ & $37 / 34$ & $\begin{array}{c}\text { alfa } 2 \mathrm{a} \\
180\end{array}$ & 800 & $\begin{array}{c}\text { FTC + } \\
\text { TDF + } \\
\text { ATV/rtv }\end{array}$ & $\begin{array}{c}\mathrm{ABC}+ \\
\mathrm{TDF}+ \\
\mathrm{ATV}\end{array}$ & 36 & yes & yes & no \\
\hline
\end{tabular}


CDC: Center for Diseases Control Classification for HIV/AIDS; VL: viral load; ALT: alanine aminotransferase; ARV: antiretroviral therapy; RVR: rapid virological response; EVR: early virological response; SVR: sustained virological response; ABC: abacavir; 3TC: lamivudine; LPV/rtv: Lopinavir/ritonavir; R: rechallenge FTC: emtricitabine; TDF: tenofovir; ATV/rtv: atazanavir/ritonavir 
Figure 1: Depict evolution of HIV-1 RNA and HCV-RNA viral load during progression of treatment $254 \times 190 \mathrm{~mm}(96 \times 96 \mathrm{DPI})$ 
Safety and efficacy of pegylated interferon and ribavirin in adolescents with human immunodeficiency virus and hepatitis $C$ virus acquired perinatally

Raffaella Rosso, Antonio Di Biagio*, Malgorzata Mikulska, Elena Nicco, Claudia Bernardini, Claudio Viscoli

Infectious Diseases Clinic, University of Genoa, San Martino Hospital, Largo R. Benzi 10, 16132, Genoa, Italy

\section{*Corresponding author:}

Antonio Di Biagio, M.D.,

Dept. of Infectious Diseases,

San Martino Hospital, University of Genoa

Largo Rosanna Benzi 10

16132 Genova, Italy

Tel. + 390105555142

Fax +390103537680

E-mail: antonio.dibiagio@hsanmartino.it 


\begin{abstract}
Limited evidence is available currently regarding the efficacy and safety of pegylated interferon and ribavirin in patients co-infected perinatally with human immunodeficiency virus (HIV) and hepatitis $\mathrm{C}$ virus (HCV). No information is available on whether or not these patients should be treated earlier for infection with HCV. This report describes four patients with HIV and HCV co-infection acquired perinatally, who were treated with pegylated interferon and ribavirin for chronic viral hepatitis caused by HCV.
\end{abstract}

Key words: hepatitis C virus, human immunodeficiency virus, adolescents, perinatal transmission, mother-to-child transmission, pegylated interferon, ribavirin. 


\section{Introduction}

Hepatitis C virus (HCV) and human immunodeficiency virus (HIV) share the same routes of infection, therefore, co-infection with $\mathrm{HCV}$ is very common in patients infected with HIV (occurring in at least $30 \%$ of cases), with significant morbidity and mortality [Alter, 2006]. HIV infection aggravates the clinical course of $\mathrm{HCV}$ infection and reduces the rate of sustained virological response to pegylated interferon (PEG-IFN) and ribavirin [Shire et al., 2007]. Coinfected individuals have higher HCV-RNA levels [Daar et al., 2001], and progress to cirrhosis and end-stage liver disease more rapidly than those with HCV infection alone [Benhamou et al, 1999].

Therefore, the best management of hepatitis $\mathrm{C}$ in adults with co-infection is still controversial. In patients who are co-infected vertically or by perinatal transmission of both viruses, the condition is even more uncertain. It is known that the prevalence of HCV in pregnant women infected with HIV ranges from $12 \%$ to $28 \%$, with mother-to-child transmission rates ranging from $3.6 \%$ to $9.5 \%$ [England et al., 2006; Landes et al., 2008], but no guidelines are available on the most appropriate clinical management. Most patients co-infected vertically have normal hepatic function and require no treatment. Management is usually based on clinical monitoring, biochemical testing of liver function, ultrasound imaging, and sometimes, liver biopsy. However, in the light of the improved efficacy and tolerability of treatment strategies in adults, children and adolescents with vertically acquired $\mathrm{HIV} / \mathrm{HCV}$ co-infection might benefit from $\mathrm{HCV}$ treatment.

From a treatment perspective, the current guidelines by the British HIV Association (BHIVA) on $\mathrm{HIV} / \mathrm{HCV}$ co-infection in adults vary depending on the timing of the diagnosis of HIV and HCV infection [Nelson et al. 2005]. If co-infection is identified before HIV therapy is indicated, treatment for HCV should be considered to elicit a better response to HIV therapy and to limit liver damage caused by some antiretroviral drugs. If co-infection is diagnosed at a point when the patient requires or is receiving combined antiretroviral treatment (cART), delaying progression of HIV takes priority over HCV treatment [Nelson et al., 2005]. Treatment of children and adolescents coinfected with HIV and HCV is complicated further by the limited number of HIV drugs available 


\section{Case reports}

The following methods were used for virological and immunological assessment: Beckman Coulter, (Fullerton, CA, USA) for CD4+ count; Versant HIV-1 RNA 3.0 assay bDNA (Siemens Medical Solutions Diagnostics, Malvern, PA, USA) for HIV-RNA level; and Cobas Ampliprep and TaqMan Roche (Molecular System Inc, Branchburg, NJ, USA) for measurement of HCV RNA.

The characteristics and outcome of the four patients described are outlined in Table 1. None of the patients had ultrasound evidence of cirrhosis.

\section{Patient 1}

A 20-year-old male Caucasian young adult with HCV (genotype 3a) and HIV-1 (clade B) infection acquired perinatally was started on PEG-IFN- $\alpha 2 \mathrm{a} 180 \mu \mathrm{g}$ once weekly and ribavirin $800 \mathrm{mg} /$ day because of persistent elevation of liver enzymes, HCV-RNA load of $7.50 \times 10^{5} \mathrm{IU} / \mathrm{mL}(5.87 \log )$, and a favorable genotype. At that point, the patient had a CD4+ cell count of 307 cells $/ \mathrm{mm}^{3}(18 \%)$ and HIV viral load of 60,000 copies $/ \mathrm{mL}$, because of suboptimal cART with tenofovir and didanosine and a lack of compliance. To improve compliance, cART was stopped when HCV treatment was introduced. A rapid viral response was observed, with undetectable HCV-RNA load at weeks 4, 12 and 24 of treatment (Figure 1). At week 12 of treatment, aspartate aminotransferase (AST) and alanine aminotransferase (ALT) reverted to normal levels (40 U/L and $26 \mathrm{U} / \mathrm{L}$, 
respectively). PEG-IFN/ribavirin were stopped at week 24, because the patient reported subcutaneous injection fatigue. No other side effect was detected throughout the treatment period. During HCV therapy, no cART was administered, because we were concerned about possible poor compliance. Nevertheless, good immunological control was maintained (CD4+ median value 289 cells $/ \mathrm{mm}^{3}$, range 243-311 cells $/ \mathrm{mm}^{3}$ ), with low HIV-RNA replication (median value 4,700 copies/mL, range 3,500-60,000 copies/mL). Sustained viral response for HCV was confirmed at the last follow-up visit 3 years after the end of treatment.

\section{Patient 2}

An 18-year-old female Caucasian young adult, with HCV (genotype 3a) and HIV-1 (clade B) infection acquired perinatally was considered suitable for HCV treatment because of persistently active hepatitis (ALT and AST 3-5 times above the upper limit of normal) and high HCV-RNA level $\left(1.42 \times 10^{6} \mathrm{IU} / \mathrm{mL}, 6.15 \mathrm{log}\right)$. At the beginning of HCV treatment, she presented with good immunological and virological status (CD4+ 474 cells $/ \mathrm{mm}^{3}, 35 \%$, HIV RNA $<50$ copies/mL) as a result of an optimal response and compliance to cART based on abacavir, lamivudine and lopinavir/ritonavir. She started PEG-IFN- $\alpha 2 \mathrm{~b} 100 \mu \mathrm{g}$ once weekly and ribavirin $800 \mathrm{mg} / \mathrm{day}$, and had undetectable HCV-RNA levels at weeks 4, 12 and 24 and at the end of therapy (Figure 1). Additionally, liver enzymes returned to normal levels at week 24 of treatment (AST $31 \mathrm{U} / \mathrm{L}$, ALT $24 \mathrm{U} / \mathrm{L})$.

PEG-IFN and ribavirin were stopped after 36 weeks because of an iatrogenic defluvium capillorum (alopecia). At the follow-up visit, 24 weeks after the end of HCV treatment, HCV RNA remained undetectable. There were no other adverse events reported during treatment; the patient continued the same cART and HIV-RNA load remained undetectable.

\section{Patient 3}




\begin{abstract}
A 15-year-old male Caucasian adolescent with vertically acquired HCV (genotype 1a) and HIV-1 (clade B) infection was started on HCV treatment with PEG-IFN- $\alpha 2 \mathrm{~b} 80 \mu \mathrm{g}$ once weekly and ribavirin $800 \mathrm{mg} /$ day because of persistently elevated levels of AST and ALT and HCV-RNA load of $4.96 \times 10^{5} \mathrm{IU} / \mathrm{mL}(5.7 \mathrm{log})$. At that time, the patient had a high CD4+ lymphocyte count $(585$ cells $\left./ \mathrm{mm}^{3}, 27 \%\right)$ and active HIV-RNA replication $(2,600 \mathrm{RNA}$ copies $/ \mathrm{mL})$. The cART regimen was based only on abacavir and lamivudine because of suboptimal compliance.
\end{abstract}

At week 4, a partial response was observed (HCV RNA $\left.5.51 \times 10^{3} \mathrm{IU} / \mathrm{mL}, \log 3.74\right)$. The complete early virological response at week 12 (HCV RNA undetectable) was followed by a breakthrough $\left(\mathrm{HCV}\right.$ RNA $9.51 \times 10^{4} \mathrm{IU} / \mathrm{mL}, 4.97 \mathrm{log}$ ) at week 24 . At week 36 , HCV treatment was discontinued and judged as a failure because of the patient's poor compliance (Figure 1). The levels of ALT and AST remained slightly above the normal values, with median levels of $47 \mathrm{U} / \mathrm{L}$ (range 31-63 U/L) and $52 \mathrm{U} / \mathrm{L}$ (range 29-78 U/L), respectively. As a result of concern about patient compliance during HCV treatment, we prescribed monotherapy with lamivudine, with good immunological control (CD4+ median value 443 cells $/ \mathrm{mm}^{3}$, range $334-585$ cells $/ \mathrm{mm}^{3}$ ) and active HIV-RNA replication (HIV-RNA median value 900 copies $/ \mathrm{mL}$, range $<50-2,600$ copies/mL) throughout the whole period of PEG-IFN/ribavirin therapy. Then, cART based on tenofovir, emtricitabine and lopinavir/ritonavir was introduced, and 12 weeks later, HIV RNA was undetectable.

At the last follow-up, 52 weeks after the end of therapy, HCV RNA was $1.02 \times 10^{6} \mathrm{IU} / \mathrm{mL}$ (6.00 log) and AST and ALT were $32 \mathrm{U} / \mathrm{L}$ and $38 \mathrm{U} / \mathrm{L}$, respectively, with undetectable HIV RNA and CD4+ cell count of 242 cells $/ \mathrm{mm}^{3}$. HCV retreatment can be considered after thorough and intense counseling, given that, as a young adult, the patient might be more responsible and compliant than as a teenager.

\title{
Patient 4
}


A 19-year-old female Caucasian young adult with HCV (genotype 3a) and HIV-1 (clade B) infection acquired perinatally started PEG-IFN/ribavirin therapy because of persistently elevated HCV RNA, and a favorable genotype. At that time, she had a high CD4+ cell count $\left(663 \mathrm{cells} / \mathrm{mm}^{3}\right.$, $36 \%)$ and active HIV-RNA replication $(10,400$ copies $/ \mathrm{mL})$ because of lack of compliance and multiple treatment failures. HCV RNA was $4.39 \times 10^{5} \mathrm{IU} / \mathrm{mL}(5.87 \mathrm{log})$, and ALT and AST were $30 \mathrm{U} / \mathrm{L}$ and $37 \mathrm{U} / \mathrm{L}$, respectively. PEG-IFN- $\alpha 2 \mathrm{~b} 80 \mu \mathrm{g}$ once weekly and ribavirin $800 \mathrm{mg} /$ day were prescribed. However, HCV RNA remained high at weeks 4 and $12\left(2.05 \times 10^{5} \mathrm{IU} / \mathrm{mL}, 5.31 \log\right.$ and $1.16 \times 10^{5} \mathrm{IU} / \mathrm{mL}, 5.06 \mathrm{log}$, respectively). At week 24 , the treatment was stopped because of failure (Figure 1).

At the beginning of $\mathrm{HCV}$ treatment, taking into account her good immunological control and failure of previous cART (abacavir, lamivudine and efavirenz), we decided to switch to monotherapy with lamivudine. This was continued for 28 weeks after the beginning of HCV treatment, with good immunological control (CD4+ median value 483 cells $/ \mathrm{mm}^{3}$, range $427-663$ cells $/ \mathrm{mm}^{3}$ ), and active HIV-RNA replication (median value 10,650 RNA copies/mL, range 3,300$15,700$ copies $/ \mathrm{mL})$.

Eight months after the new cART based on tenofovir, emtricitabine and ritonavir-boosted atazanavir was started. This resulted in a good immunological/virological situation (CD4+ cell count of 681 cells $/ \mathrm{mm}^{3}$, HIV RNA undetectable), HCV RNA was $5.19 \times 10^{4} \mathrm{IU} / \mathrm{mL}$ (4.72 log), and AST and ALT were $34 \mathrm{U} / \mathrm{L}$ and $37 \mathrm{U} / \mathrm{L}$, respectively. Therefore, new treatment with PEG-IFN- $\alpha 2 \mathrm{a}$ $180 \mu \mathrm{g}$ once weekly and ribavirin $800 \mathrm{mg}$ /day was started. A rapid virological response was present at week 4 and HCV RNA remained undetectable at weeks 12 and 24. However, at week 36, virological breakthrough was detected $\left(6.74 \times 10^{5} \mathrm{IU} / \mathrm{mL}, 5.82 \mathrm{log}\right)$ and $\mathrm{HCV}$ treatment was stopped (Figure 1). At the follow-up visit after 8 weeks, HCV-RNA level was high $\left(1.23 \times 10^{6}\right.$ $\mathrm{IU} / \mathrm{mL}, 6.08 \mathrm{log}$ ) but AST and ALT levels were normal. No adverse effect occurred during the PEG-IFN/ribavirin therapy. 
Three months later, the patient experienced gastrointestinal intolerance to ritonavir, which lead to poor compliance and an increase in HIV RNA. Thus, the cART was changed successfully to abacavir, lamivudine and atazanavir without ritonavir-boosted $\left(\mathrm{CD} 4+\right.$ cell count $635 \mathrm{cells} / \mathrm{mm}^{3}$, HIV RNA undetectable).

\section{Discussion}

In adolescents with HIV and HCV acquired perinatally, the clinical and therapeutic approach to chronic $\mathrm{HCV}$ infection remains undefined. Selecting these patients for antiviral therapy is challenging given the incomplete understanding of the natural history of HCV infection in adolescents and the side effects associated with treatment. The introduction of PEG-IFN in adults has improved response rates, and it could be an attractive option in adolescents because of its weekly dosing.

To date, up to $40 \%$ of $\mathrm{HIV} / \mathrm{HCV}$ co-infected adults can achieve a sustained virological response with PEG-IFN/ribavirin, and the ability to achieve such a response depends on adhering to recommended doses of both drugs and on patient compliance [Sulkowski \& Benhamou, 2007]. The outcome of this combined treatment in terms of sustained virological response is known to be less favorable in HCV/HIV co-infected patients than in those infected with HCV alone [Chung et al., 2004], and seems to be associated with HCV genotype, HIV RNA and CD4+ cell count [Sulkowski, 2008], even if recent studies have suggested a non-predictive role of immunological and virological status in treatment response [Quesnel-Vallières et al., 2008].

The rates of HCV-RNA clearance are significantly higher in cART-treated than in untreated adult patients, regardless of HCV genotype [Sulkowski, 2008]. Moreover, several studies in adults have suggested that duration of infection might be more important than virus genotype in the progression of $\mathrm{HCV}$-associated liver disease [Rockstroh et al., 2008]. 
In untreated children and adolescents, only few data are available, but the clearance is associated independently with genotype 3 and with infection diagnosed early in life [Resti et al., 2003].

In this limited study, adolescents with HIV and HCV acquired perinatally seem to respond well to PEG-IFN and ribavirin. Indeed, patients 1 and 2 presented a rapid virological response and subsequent sustained virological response. However, both patients had genotype 3 and good immunological control during HCV treatment. The other two patients failed PEG-IFN and ribavirin treatment, probably because of problems with compliance. Indeed, patient 3, with a less responsive genotype (1b) failed HCV treatment despite an early virological response. Patient 4, with a favorable genotype, initially did not respond to HCV treatment when she had high HIV-RNA levels. After HIV viral load became undetectable, she responded rapidly to PEG-IFN/ribavirin retreatment but eventually she failed because of poor compliance.

Although the study was limited by its small sample size and retrospective nature, in young adults with vertically acquired HCV/HIV co-infection, PEG-IFN/ribavirin therapy seems to show promising efficacy similar to that described in adults. No liver biopsy was performed before treatment, according to the most recent guidelines for $\mathrm{HCV}$ management in co-infected adult patients. Indeed, given the high response rate to treatment based on PEG-IFN/ribavirin, the faster progression of hepatic disease in co-infected patients, and the possibility of evaluating treatment response by monitoring HCV RNA, liver biopsy is no longer mandatory [Rockstroh et al., 2008].

In the setting of co-infection, the recommended length of PEG-IFN/ribavirin treatment is 48 weeks, regardless of genotype and response to therapy. Even though in all patients HCV treatment was planned for 48 weeks, it was always stopped earlier, either because of side effects/intolerance (alopecia and subcutaneous injection fatigue) or failure due to poor compliance. As far as tolerability is concern, it is stressed that PEG-IFN/ribavirin generally was well tolerated and none of our patients experienced leukopenia or anemia, therefore, there was no need to use erythropoietin or granulocyte-stimulating factors. 
In conclusion, $\mathrm{HCV}$ treatment should be standardized in subjects with vertically acquired HCV/HIV co-infection, on the basis of its efficacy and tolerability. Although our four patients had been co-infected with $\mathrm{HIV} / \mathrm{HCV}$ since birth, all but one had to wait 18 years before receiving $\mathrm{HCV}$ treatment. Given the long history of co-infection in these patients, starting HCV treatment early might prevent the development of chronic liver failure, hepatocellular carcinoma and cirrhosis. Moreover, early treatment in children might result in a better response. The main problems in adolescent patients remain lack of compliance, mostly because of age, the burden of pills, difficult management of subcutaneous injection, possible adverse events associated with PEG-IFN/ribavirin, and the difficult socio-cultural background of these patients. Good compliance is essential to achieve a sustained virological response and appeared to be a major determinant of treatment failure in the patients described. The balance of risks and benefits in the treatment of HCV and HIV infection in adolescent patients should be assessed individually. Preparation and support throughout the treatment period, both for the patient and for his/her family are needed to improve adherence and obtain a high probability of therapeutic success.

\section{Acknowledgements}

We thank all the patients who participated in the study and the nurses who cared for these patients.

Funding Source: None.

Competing interests: None declared 


\section{References}

Alter MJ. 2006 Epidemiology of viral hepatitis and HIV co-infection. J Hepatol 44:S6-S9.

Benhamou Y, Bochet M, Di Martino V, Charlotte F, Azria F, Coutellier A, Vidaud M, Bricaire F, Opolon P, Katlama C, Poynard T. 1999 Liver fibrosis progression in human immunodeficiency virus and hepatitis C virus co-infected patients. Hepatology 30:1054-8 Chung RT, Andersen J, Volberding P Robbins GK, Liu T, Sherman KE, Peters MG, Koziel MJ, Bhan AK, Alston B, Colquhoun D, Nevin T, Harb G, van der Horst C; AIDS Clinical Trials Group A5071 Study Team. 2004 Peginterferon alfa 2a plus ribavirin versus interferon alfa-2a plus ribavirin for chronic hepatitis C in HIV-coinfected persons. N Engl J Med 351,451-9.

Daar ES, Lynn H, Donfield S, Gomperts E, Hilgartner MW, Hoots WK, Chernoff D, Arkin S, Wong WY, Winkler CA. 2001; Hemophilia Growth and Development Study 2001 Relation between HIV-1 and hepatitis C viral load in patients with hemophilia. J Acquir Immune Defic Syndr 26:466-72

England K, Thorne C, Newell ML. 2006 Vertically acquired pediatric coinfection with HIV and hepatitis C virus. Lancet Infect Dis 6:83-90.

England K, Thorne C, Pembrey L, Newell ML. 2009 Policies and practices for the clinical management of $\mathrm{HIV} / \mathrm{HCV}$ coinfected children in Europe: an epidemiological survey. Eur $\mathbf{J}$ Pediatr 168:915-917

Jacobson KR, Murray K, Zellos A Schwarz KB. 2002 An analysis of published trials of interferon monotherapy in children with chronic hepatitis C. J Pediatr Gastroenterology Nutr $34,52-58$.

Landes M, Newell ML, Barlow P, Fiore S, Malyuta R, Martinelli P, Posokhova S, Savasi V, Semenenko I, Stelmah A, Tibaldi C, Thorne C. 2008 Hepatitis B or Hepatitis C coinfection in HIV-infected pregnant women in Europe. HIV Med 9, 526-34.

Nelson M, Matthews G, Brook MG et al. 2005 BHIVA guidelines on HIV and chronic hepatitis: coinfection with HIV and hepatitis C virus infection. HIV Med 6:96-106 
Quesnel-Vallières M, Lemay M, Lapointe N, Martin SR, Soudeyns H. 2008 HCV quasispecies evolution during treatment with interferon alfa- $2 \mathrm{~b}$ and ribavirin in two children coinfected with HCV and HIV-1. J of Clin Virol 43, 236-40.

Resti M, Jara P, Hierro L, Azzari C, Giacchino R, Zuin G, Zancan L, Pedditzi S, Bortolotti F. 2003 Clinical features and progression of perinatally acquired hepatitis c virus infection. J Med Virol 70, 373-7.

Rockstroh JK, Bhagani S, Benhamou Y, Bruno R, Mauss S, Peters L, Puoti M, Soriano V, Tural C, EACS Executive Committee 2008. European AIDS Clinical Society (EACS) guidelines for the clinical management and treatment of chronic hepatitis B and C coinfection in HIV-infected adults. HIV Med 9:82-8.

Shire NJ, Welge JA, Sherman KE. 2007 Response rates to pegylated interferon and ribavirin in HCV/HIV coinfection: a research synthesis. J Viral Hepat 14:239-48.

Sulkowski M.S, Benhamou Y. 2007 Therapeutic issues in HIV/HCV-coinfected patients. J Viral Hepat 14:371-86.

Sulkowski M.S. 2008 Viral hepatitis and HIV coinfection. J Hepatol 48:353-67. 